\title{
MEDICINE
}

\section{SUBMICROSCOPIC CHANGES OF STRUCTURAL COMPONENTS OF THE SPLEEN DUE TO THE ACTION OF MONOSODIUM GLUTAMATE}

\author{
Tetiana Harapko, \\ Department of Human Anatomy and Histology, Uzhhorod National University, Medical Faculty, \\ Uzhhorod, Ukraine, ORCID ID: https://orcid.org/0000-0003-0596-9622 \\ Lesia Mateshuk-Vatseba \\ Department of Normal Anatomy, Lviv National Medical University named after Danylo Halytskyi, \\ Lviv, Ukraine, ORCID ID: https://orcid.org/0000-0002-3466-5276
}

DOI: https://doi.org/10.31435/rsglobal_wos/30062020/7126

\section{ARTICLE INFO}

Received: 12 April 2020

Accepted: 06 June 2020

Published: 30 June 2020

\section{KEYWORDS}

spleen,

rat,

lymphocytes,

macrophages,

monosodium glutamate,

exposure

\begin{abstract}
The results of an experimental study conducted on white male rats and females of reproductive age were analyzed in order to detect submicroscopic changes in the structural components of the spleen under the action of monosodium glutamate in the dynamics. For two, four, six and eight weeks, the animals received monosodium glutamate at a dose of $0.07 \mathrm{~g} / \mathrm{kg}$ body weight daily with food. Sections of the spleen were made on a UMTP-6M ultramicrotome with a diamond knife (DIATOM) and double contrast was performed according to Reynolds and uranyl acetate. Submicroscopic examinations of the organ were performed using an electron transmission microscope TEM-100. The investigated material was photodocuted using a SONY - H9 digital camera. The first violations of the structural components of the spleen are observed after two weeks, namely the expansion of intercellular spaces in both white and red pulp of the spleen, which contain vacuole-like structures, an increase in plasma cells, the cytoplasm of which is filled with dilated tubules. In dynamics with increase in duration of reception changes deepen, reaching a maximum in 8 weeks of experiment. Electron microscopy revealed that the signs of adaptive-compensatory processes by the end of the experiment lead to a loss of regenerative function.
\end{abstract}

Citation: Tetiana Harapko, Lesia Mateshuk-Vatseba. (2020) Submicroscopic Changes of Structural Components of the Spleen Due to the Action of Monosodium Glutamate. International Academy Journal Web of Scholar. 6(48). doi: 10.31435/rsglobal_wos/30062020/7126

Copyright: (C) 2020 Tetiana Harapko, Lesia Mateshuk-Vatseba. This is an open-access article distributed under the terms of the Creative Commons Attribution License (CC BY). The use, distribution or reproduction in other forums is permitted, provided the original author(s) or licensor are credited and that the original publication in this journal is cited, in accordance with accepted academic practice. No use, distribution or reproduction is permitted which does not comply with these terms.

Introduction. Due to the growing prevalence of food supplements on the market, we were interested in whether they affect the structure of the immune system, including the spleen. This is a secondary organ of the lymphoid (immune) system, where antigen-dependent proliferation and differentiation of T- and B-lymphocytes coming from the vascular bed [16]. The organ carries out immune control of the blood flowing from the aorta to the portal vein of the liver. In addition, "spent" blood cells, antigens and other foreign compounds are destroyed in the spleen [7, 9, 13]. Not surprisingly, this organ has been of interest to morphologists for decades. The literature describes changes in the spleen under the action of nanoparticles of silicon dioxide and lead acetate [2], 
epichlorohydrin [18], bioactive substances [17], drugs [5], radiation exposure [19], burns and after correction with infusion solution HAES- LX-5\% [6, 12] and others.

One of the most common food additives in Ukraine and around the world is monosodium glutamate [3, 4]. It has flavor enhancer properties, thereby increasing the amount of food consumed, which leads to a high-calorie diet and is the drug of choice for reproducing the model of experimental obesity in animals $[4,20]$. Morphologists study the effect of monosodium glutamate on the ovaries [11], fallopian tubes [10], testicles [1], brain [14] and others. In the literature there is some data on the effect of monosodium glutamate on the spleen, but there is no information about its effect in the dynamics, about submicroscopic changes in the cellular composition of the organ.

The purpose of the study: to study the electron microscopic changes in the parenchyma of the spleen of rats under the action of monosodium glutamate in the dynamics.

Material and methods.

The experimental study was performed on 66 white male and female rats of reproductive age (2.5-6.5 months) weighing 120-250 g. The electron microscopic structure of the spleen of white rats under physiological norms was studied in 10 intact animals. The experimental animals were divided into 4 groups, each with 10 animals: the first group - animals that received a high-calorie diet (HCD) for two weeks; the second group - for four; the third group - for six; the fourth group received HCD for eight weeks. There were 5 male rats and 5 female rats in each group. HCD was obtained by adding to the diet of monosodium glutamate at a dose of $0.07 \mathrm{~g} / \mathrm{kg}$ body weight of rats.

The control group consisted of 16 white rats ( 8 male rats and 8 female rats), which received a standard vivarium diet instead of VKD.

All experimental animals were kept in the vivarium of Lviv National Medical University named after Danylo Halytskyi. The research was conducted in accordance with the provisions of the "European Convention for the Protection of Vertebrate Animals Used for Experimental and Other Scientific Purposes" (Strasbourg, 1986), in accordance with Council Directives 86/609 / EEC (1986), Law of Ukraine №3447 - IV "From cruel treatment", general ethical principles of animal experiments, approved by the First National Congress of Ukraine on Bioethics (2001).

Before sampling the animals were anesthetized with anesthesia with diethyl ether. Fixation of pieces of the spleen was performed with a $1.5 \%$ solution of osmium tetroxide in $0.2 \mathrm{M}$ monosodium cacodyl solution at $\mathrm{pH} 7.2$ for $2-2.5$ hours in the cold. Dehydration in increasing concentrations of ethyl alcohol $\left(50^{\circ}, 70^{\circ}, 90^{\circ}\right.$ and absolute $)$ for 30 minutes each and propylene oxide for 10 minutes. The material was poured into a mixture of epoxy resins and polymerized for $24 \mathrm{~h}$ in a thermostat at $60^{\circ} \mathrm{C}$. Sections were made on an ultramicrotome UMTP-6M with a diamond knife (DIATOM) and double contrast was performed according to Reynolds and uranyl acetate. Submicroscopic examinations of the organ were performed using an electron transmission microscope TEM-100. The investigated material was photodocuted using a SONY - H9 digital camera.

Results. The electron microscopic structure of the spleen of white rats of males and females of reproductive age of the intact and control groups corresponds to the species norm. Externally, the body is surrounded by a fibrous membrane, from which the spleen transfers depart inwards. The support and contraction apparatus of the spleen is represented by a capsule and trabeculae, which contain collagen and elastic fibers, bundles of smooth myocytes. White pulp is formed by lymphocytes, plasma cells, macrophages, dendritic and interdigitating cells. The accumulation of these cells forms lymphatic follicles. The red pulp is formed by the accumulation of shaped elements of blood, which are surrounded by reticular cells or in the sinuses of the spleen. In the germinal center of the lymph nodes are concentrated mainly B-lymphocytes, and in the periarterial zone T-lymphocytes. Small lymphocytes have a small rounded nucleus, which is surrounded by a thin section of cytoplasm (Fig. 1). Medium lymphocytes have a lower nuclear-cytoplasmic ratio than small lymphocytes, the cytoplasm contains mitochondria and granular endoplasmic reticulum (GES). Large lymphocytes contain a nucleus with a predominance of euchromatin. Reticular cells have elongated nuclei with clear contours of the karyolemma. Their plasmolemma forms processes by which they form cellular contacts, form splenic cords. Plasmocytes and macrophages have a characteristic structure. The cytoplasm of macrophages is moderately loaded with parts of the nuclei of other cells and remnants of blood cells. Plasmocytes are clearly distinguished from other cells by an eccentrically located nucleus and typical chromatin condensation. 


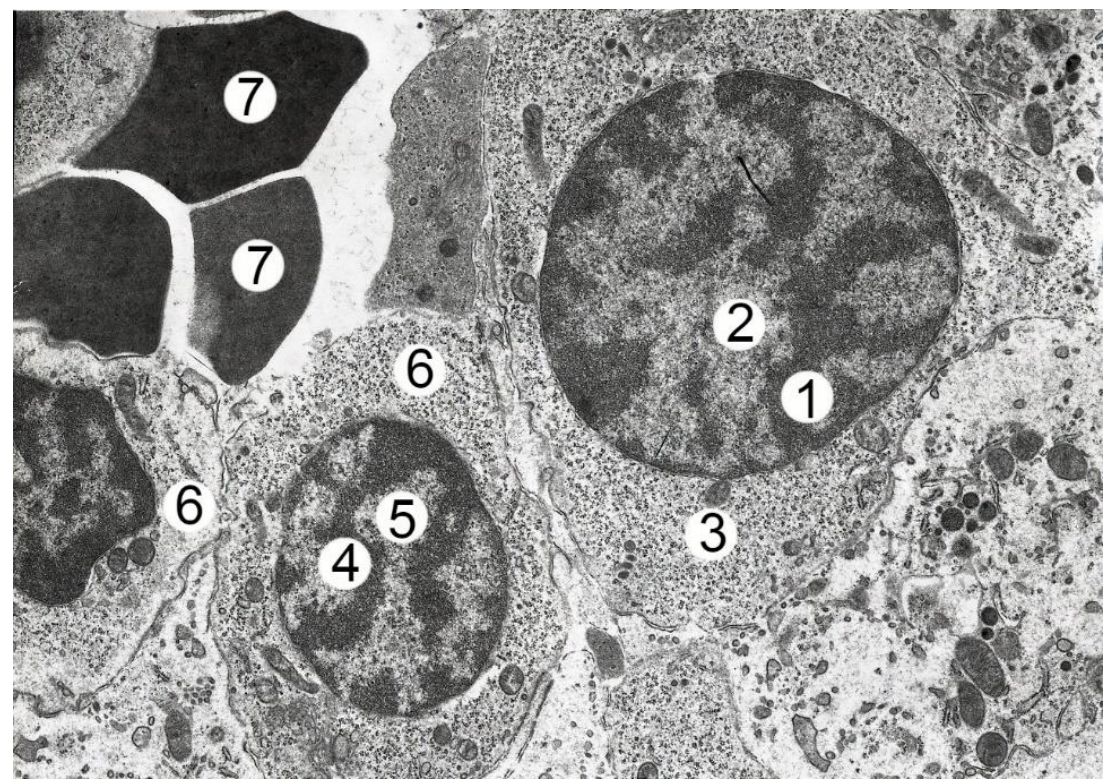

Fig. 1. Electron microscopic organization of a fragment of the red pulp of the spleen of a white rat male intact group. Electronic micrograph. Approx. $\times 8000$. Designation: heterochromatin (1) and euchromatin (2) in the nucleus of the middle lymphocyte; 3 - cytoplasm of the middle lymphocyte; heterochromatin (4) and euchromatin (5) in the nucleus of a small lymphocyte; 6 - cytoplasm of a small lymphocyte; 7 - erythrocytes.

After two weeks of the experiment, the somewhat expanded intercellular spaces in both the white and red pulp of the spleen contain vacuole-like structures, which can be explained by edema of the parenchyma of the organ. The number of plasma cells has increased, their cytoplasm is filled with dilated tubules of the granular endoplasmic reticulum (Fig. 2).

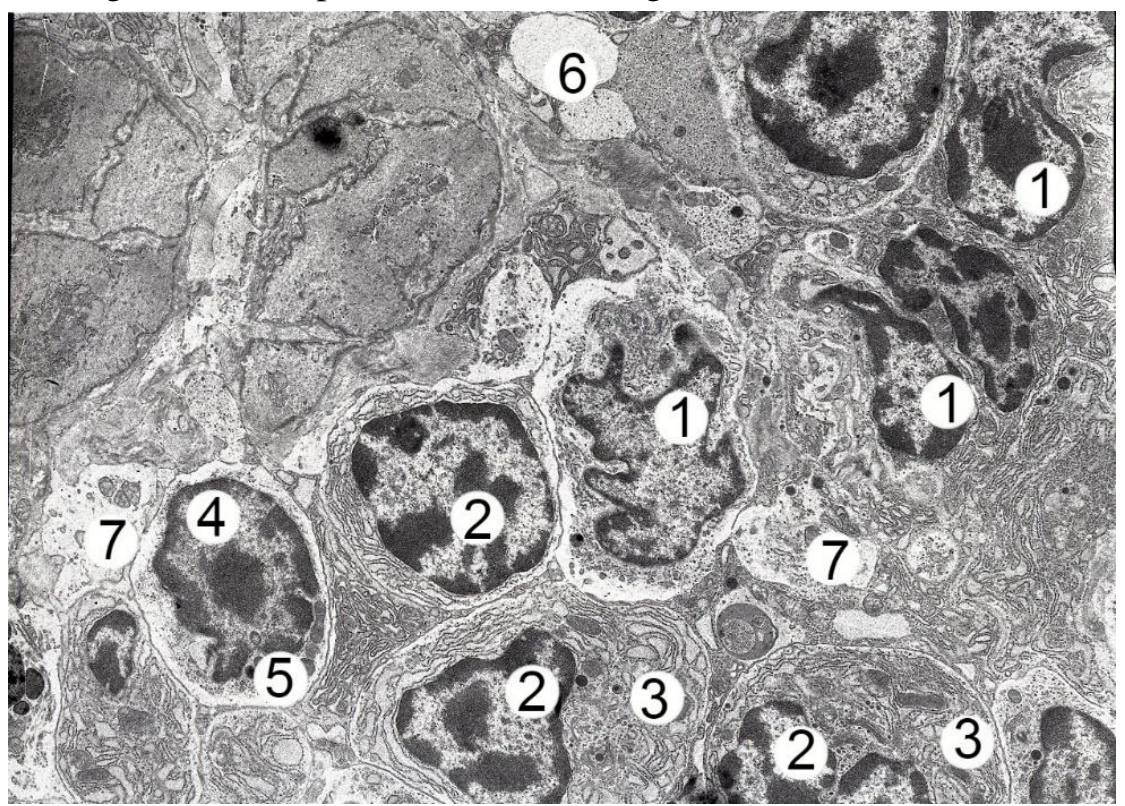

Fig. 2. Electron microscopic organization of a fragment of the white pulp of the spleen of a white female rat after two weeks of HCD. Electronic micrograph. Approx. $\times 4000$. Designation:

1 - polysegmental neutrophil; 2 - plasma cell nucleus; 3 - plasma cell cytoplasm contains dilated tubules of the granular endoplasmic reticulum; nucleus (4) and cytoplasm (5) of a small lymphocyte; 6 - vacuole-like structures; 7 - expanded intercellular space.

After four weeks of the experiment, electron microscopic study of the structure of the spleen of white rats of males and females of reproductive age revealed an increase in the number of active macrophages in the parenchyma of the organ. Their cytoplasm is loaded with fragments of nuclei of other cells, parts of "undigested" shaped elements of blood, contains numerous phagosomes. The 
proportion of reticular cells and connective tissue fibers in both splenic trabeculae and pulpal cords has increased. The nuclei of reticular cells are elongated, the contour of the karyolemma is not smooth, tortuous, the processes of plasmolema are thinned (Fig. 3).

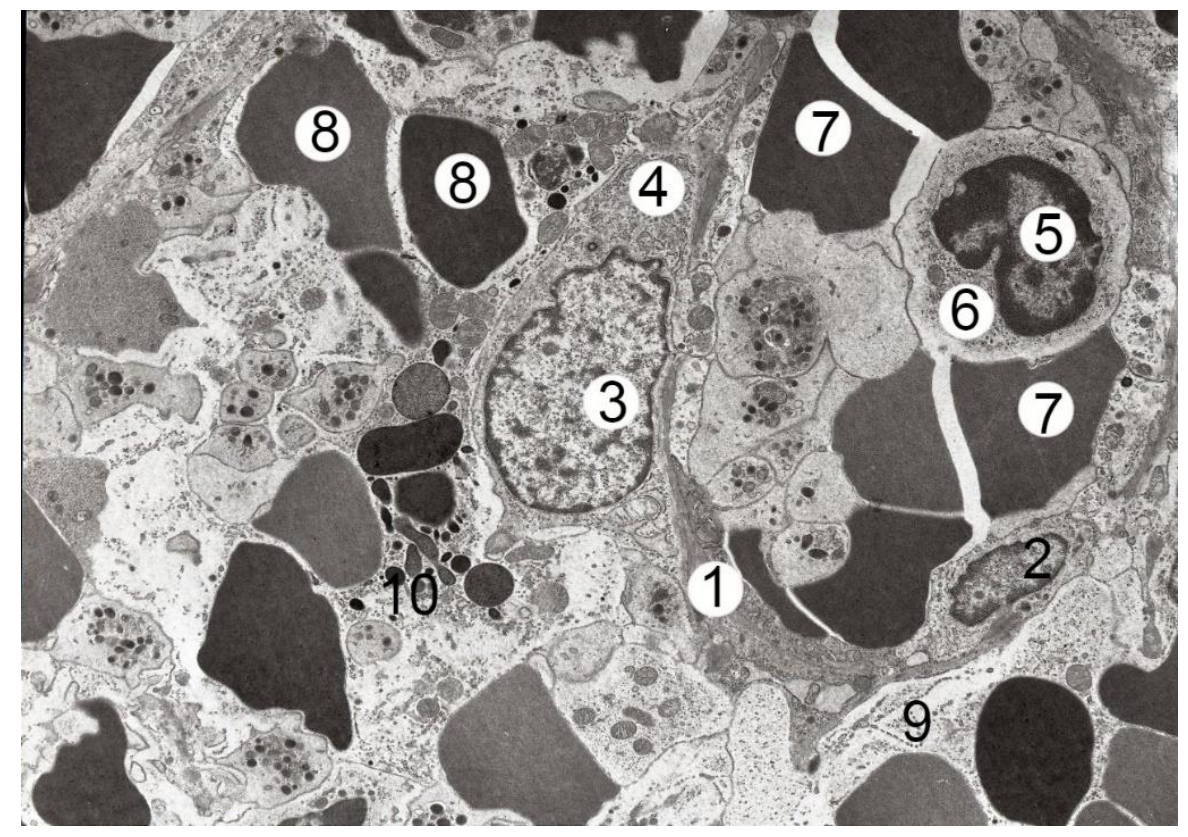

Fig. 3. Electron microscopic organization of a fragment of the red pulp of the spleen of a white female rat after four weeks of HCD. Electronic micrograph. Approx. $\times 4000$. Designation: $1-$ thickened wall of the splenic sinus; 2 - interdigitating cell; the nucleus (3) and cytoplasm (4) of the reticular cell; the nucleus (5) and cytoplasm (6) of a small lymphocyte in the lumen of the sinusoid; erythrocytes in the lumen of the sinusoid (7) and beyond (8); 9 - perivascular edema; 10 - osmophilic (fatty) inclusions.

After six weeks of the experiment, there are signs of adaptive-compensatory processes in the organ. The number of lymphocytes with signs of apoptosis at different stages (karyopyknosis, karyorrhexis, karyolysis) increased, the number of cells with signs of mitosis decreased (Fig. 4). Small and medium-sized lymphocytes and lymphoblasts are mainly located in the germinal center, the nuclei of the latter contain lumps of condensed chromatin on the inner surface of the karyolemma, the nucleolus is not clearly visualized. Dendritic cells are located between the accumulation of lymphocytes. In their cytoplasm organelles with signs of damage, namely mitochondria with a swollen matrix, GES is represented by short dilated tubules. The periarterial zone is dominated by small and medium lymphocytes, there are signs of edema. Small and medium lymphocytes are concentrated in the mantle zone, the shape of the nuclei is oval, the karyolemma is not smooth, it forms a protrusion. The cytoplasm is enlightened, contains a small number of slightly altered organelles. In the marginal zone, in addition to lymphocytes, there is a large number of active macrophages, the cytoplasm contains osmophilic (fat) inclusions, the remains of phagocytosed cells.

The red pulp is full-blooded, contains areas of accumulation of deformed blood cells, polysegmental neutrophils and megakaryocytes. Sinusoidal hemocapillaries are dilated, in their wall there are large gaps for the passage of cells.

After eight weeks of the study, all changes are similar to the previous term of the experiment, but the signs of adaptive-compensatory processes are more shifted to the loss of regenerative function. Both white and red spleen pulp of white male and female rats showed a significant increase in the number of plasma cells and active macrophages. The nuclei of plasma cells contain mainly euchromatin, condensed heterochromatin is located near the karyolemma. The cytoplasm is mainly filled with wide tubules of GES and tanks of the Golgi apparatus. Ribosomes are few, mitochondria with damaged crystals. Macrophages are filled with cell fragments, osmophilic (fatty) inclusions, phagocytosed parts of erythrocytes. A common phenomenon is the death of a macrophage completely filled with inclusions (Fig. 5). Reticular fibers in the composition of the Cords of Billroth's are swollen, thickened. Erythrocytes and thrombocytes not only fill the lumen of the sinuses of the spleen, but also accumulate 
in the splenic cords. Lymphocytes in the white pulp have polymorphic nuclei, the cytoplasm is enlightened, contains almost no organelles, most of the cells at different stages of apoptosis.

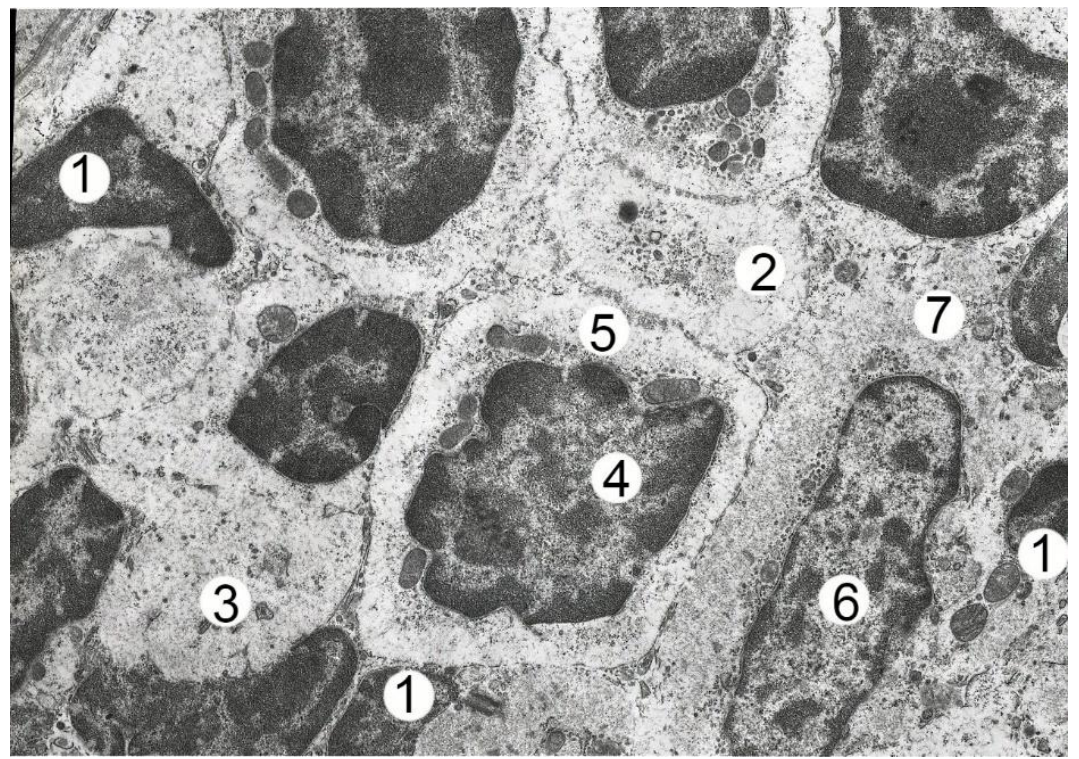

Fig. 4. Electron microscopic organization of a fragment of the white pulp of the spleen of a white male rat after six weeks of HCD. Electronic micrograph. Approx. $\times 6000$. Designation: 1 - deformed lymphocyte nuclei with signs of karyopyknosis; 2 - destructuring area; 3 - enlightened area of the cytoplasm, without organelles; nucleus (4) and cytoplasm (5) of the middle lymphocyte; nucleus (6) and enlightened cytoplasm (7) of the reticular cell.

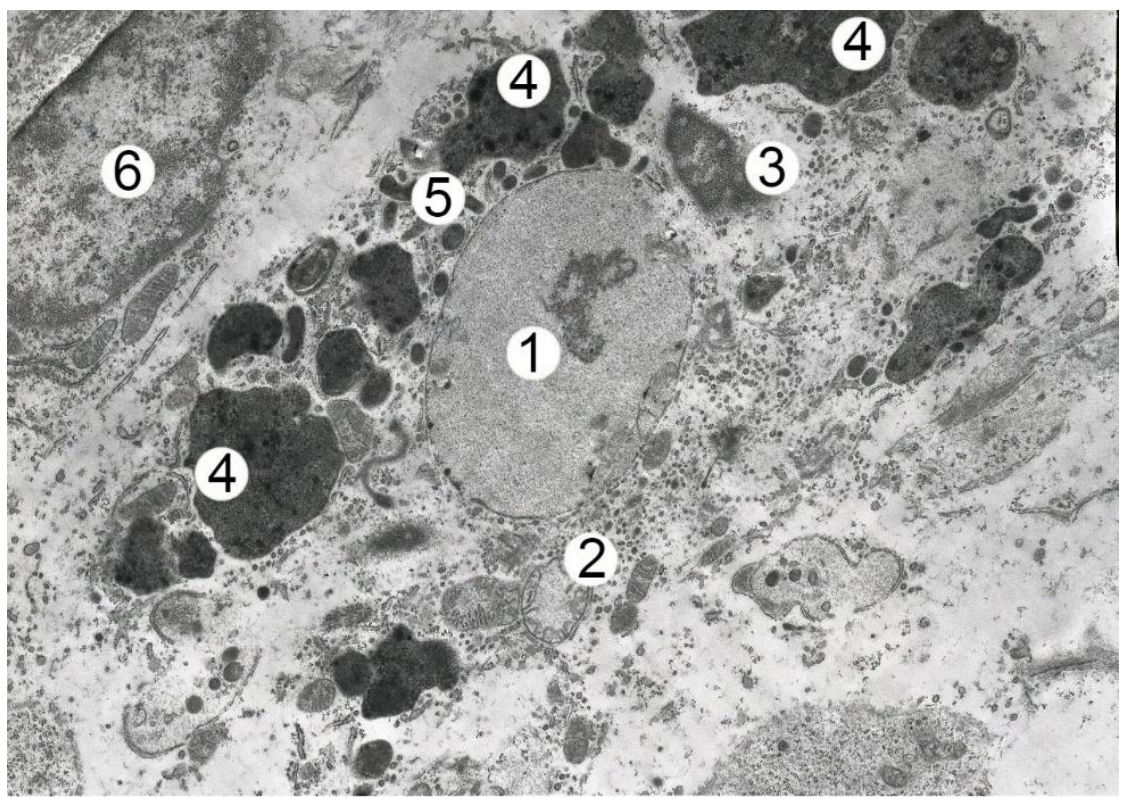

Fig. 5. Electron microscopic organization of a fragment of the red pulp of the spleen of a white male rat after eight weeks of HCD. Electronic micrograph. Approx. $\times 8000$. Designation: a macrophage in a state of apoptosis contains a nucleus (1) with signs of karyorrhexis, swollen ribosomes (2) in the cytoplasm, remnants of the nucleus (3) of another cell, hemosiderin (4), osmophilic (fatty) inclusions (5); 6 - reticular cell in the thickness of the splenic cord.

Discussion. Zeinab A. Hassan and co-authors [15] describe studies in adult rats using monosodium glutamate daily at a dose of $3 \mathrm{~g} / \mathrm{kg}$ per day for 8 weeks. Histological examination showed that monosodium glutamate causes disturbances in the lobular structure of the thymus, significantly reduces the number of T-lymphocytes, expanding hemocapillaries in the cortical substance. The relative area of the medullary substance of the thymus increases, the vessels are full of blood. The boundary between cortical and medullary substances is not clear. The spleen is small, 
lymph follicles without a germinal center, blood vessels are overflowing, the number of $\mathrm{T}$ lymphocytes in the parenchyma decreases. The authors recommend reducing the amount of monosodium glutamate in foods.

Ćirić Milan and the co-authors [7] conducted an experiment on newborn rats, which on the 2nd, 4th, 6th, 8th and 10th day of life were injected subcutaneously with monosodium glutamate at a dose of $4 \mathrm{mg} / \mathrm{g}$ body weight. This led to the defeat of the arcuate, paraventricular and ventromedian nuclei of the hypothalamus. Damage to these structures led to a functional disorder in the hypothalamic-pituitary-adrenocortical chain. Four months later, the animals were removed from the experiment. On histological specimens, the authors found atrophy of the spleen pulp. Germinative centers in lymphatic follicles are absent, in the red pulp of the spleen a large number of hemosiderophages and hematopoietic elements, especially megakaryocytes.

Ebaid H.M. with the co-authors [8] studied the histological effect of monosodium glutamate as a dietary supplement on the spleen of adult Wistar rats. Experimental animals received monosodium glutamate at a dose of $4 \mathrm{mg} / \mathrm{kg}$ body weight for fourteen days. Rats were removed from the experiment the day after the last administration of monosodium glutamate, as well as on the 14th, 28th and 42nd day after the cessation of its administration. Immediately after cessation of administration in animals, atrophic changes in the white pulp of the spleen and stagnation in the red pulp were detected. In groups of animals after 14 and 28 days, vacuolation of some spleen cells with reduced cell density was detected, and sinusoidal spaces were expanded. After 42 days, changes in the spleen were less pronounced.

Somewhat similar changes are described by the authors [17] under the action of $2 \mathrm{ml}$ of mountain arnica extract per $20 \mathrm{~g}$ of mouse weight, which was added to the feed. There were significant changes in the spleen of animals. Lymphoid follicles have lost a clear structure, significantly increased in the field of view of the microscope the number of megakaryocytes over the entire area of the parenchyma of the organ. The increase in their number is a sign of a compensatory response of the body in response to immunopathological effects, it is a sign of imbalance, in which there is damage to immunogenesis, including bone marrow as a system of immunogenesis and as a hematopoietic system. Also, this phenomenon can be considered as a phenomenon of restructuring of the immune system in response to its activation by biologically active substances.

Conclusions. As a result of daily addition of monosodium glutamate to the diet of white male and female rats, the first violations of the structural components of the spleen are observed in two weeks, namely the expansion of intercellular spaces in both white and red spleen pulp containing vacuole-like structures, increased plasma cell counts, the cytoplasm of which is filled with dilated tubules of the GES. In dynamics with increase in duration of reception changes deepen, reaching a maximum in 8 weeks of experiment. Electron microscopy revealed that the signs of adaptivecompensatory processes by the end of the experiment lead to a loss of regenerative function.

Declaration of Interest Statement. The authors report no conflict of interest and the article is not funded or supported by any research grant.

\section{REFERENCES}

1. Alalwani, A.D. (2014), «Monosodium glutamate induced testicular lesions in rats (histological study)». Middle East Fertil Soc J., 19, 274-80. https://doi.org/10.1016/j.mefs.2013.09.003.

2. Bandas, I.A., Kulitska, M.I., Korda, M.M. (2017), «Strukturni zminy pechinky, nyrok ta selezinky shchuriv pry dii nanochastynok dioksydu kremniiu ta atsetatu svyntsiu». Visnyk problem biolohii i medytsyny, 1, 322-327. http://nbuv.gov.ua/UJRN/Vpbm_2017_1_70.

3. Bautista, R.J.H., Mahmoud, A.M., Königsberg, M., Guerrero, N.E.L.D. (2019), Obesity: Pathophysiology, monosodium glutamate-induced model and anti-obesity medicinal plants. Biomedicine \& Pharmacotherapy, 111, 503-516. https://doi.org/10.1016/j.biopha.2018.12.108.

4. Beltiukova, SV. (2016), «Determination of monosodium glutamate thin-layer chromatography method with detection fluorescent». Visnyk ONU. Khimiia.;1 (57), 50-58.

5. Bobrysheva, I.V. (2013), «Ultramikroskopicheskoe issledovanie selezenki krys raznykh periodov postnatalnogo ontogeneza posle vvedeniia imunofana», Zhurnal Grodnenskogo gosudarstvennogo meditsinskogo universiteta, 4,56-60.

6. Bulko, I.V. (2016), «Strukturni zminy v selezintsi shchuriv u piznikh stadiiakh opikovoi travmy pislia korektsii infuziinym rozchynom HAES-LX-5\%». Visnyk problem biolohii i medytsyny, 360-363.

7. Ciric, M., Cekic, S., Pavlovic, V., Jovic, Z. and Tasic, G. (2005), «Histopathological changes In spleen of rats treated with monosodium glutamate». Acta Fac. Med. Naiss, 22,191-194. 
8. Ebaid, H.M., Tag, H.M. (2012), «Monosodium glutamate toxic effect on spleen structure and potential of recovery in adult albino rats». Egypt Acad J Biol Sci, 4, 1-8. https://doi.org/10.21608/EAJBSZ.2012.13513.

9. El-Aziza, R., Naguiba, M., Rashedb, L. (2018), «Spleen size in patients with metabolic syndrome and its relation to metabolic and inflammatory parameters». The Egyptian Journal of Internal Medicine, 30, 78-82. https://doi.org/10.4103/ejim.ejim_86_17.

10. Eweka, A.O., Eweka, A., Om'iniabohs, F.A.E. (2010), Histological Studies of the Effects of Monosodium Glutamate of the Fallopian Tubes of Adult Female Wistar Rats. North American Journal of Medical Sciences.2010;2(3):146-149. https://doi.org/10.4297/najms.2010.3146.

11. Eweka, A.O., Om'iniabohs, F.A.E. (2011), «Histological Studies of the Effects of Monosodium Glutamate on the Ovaries of Adult Wistar Rats». Annal of Medical \& Health Sciences Research, 1 (1), 37-43.

12. Gavrylyuk-Skyba, G.O., Volkov, K.S., Nebesna, Z.M. (2013), «Dynamika zmin mikrometrychnykh ta morfometrychnykh pokaznykiv selezinky pislya eksperymentalnoyi termichnoyi travmy». Biomedical and biosocial anthropology, 20, 45-48.

13. Gotoh, K., Inoue, M., Masaki, T., Chiba, S., Shimasaki, T., Ando, H. et al. (2012), «A novel antiinflammatory role for spleen-derived IL-10 in obesity-induced hypothalamic inflammation». $J$ Neurochem, 120, 752-764.

14. Hashem, H.E., El-Din Safwat, M.D., Algaidi, S. (2012), «The effect of monosodium glutamate on the cerebellar cortex of male albino rats and the protective role of vitamin $\mathrm{C}$ (histological and immunohistochemical study)». J Mol Histol. 43 (2), 179-186. https://doi.org/10.1007/s10735-011-9380-0.

15. Hassan, Z.A., Arafa, M.H., Soliman, W.I., Atteia, H.H., Al-Saeed, H.F. (2014), «The Effects of Monosodium Glutamate on Thymic and Splenic Immune Functions and Role of Recovery (Biochemical and Histological study)». J Cytol Histol, 5, 283. https://doi.org/10.4172/2157-7099.1000283.

16. Liu, C., Li, M., Cao, Y., Qu, J.P., Zhang, Z.W., Xu, S.W., Li, S. (2014), «Effects of avermectin on immune function and oxidative stress in the pigeon spleen». Chem Biol Interact, 210, 43-50. https://doi.org/10.1016/j.cbi.2013.12.015.

17. Shemediuk, N.P., Zaitsev, O.O., Butsiak. V.I. (2010), «Histolohichni zminy selezinky, pechinky, nyrok tvaryn za dii bioaktyvnykh rechovyn». Sovremennye problemy toksikologii, 2-3, 54-57.

18. Voloshin, V.M. (2012), «Vyvchennya ingalyatsiynogo vplyvu epikhlorgidrynu na organometrychni pokaznyky selezinky statevozrilykh shchuriv». Tavricheskiy mediko-biologicheskiy vestnik. 15, 1 (57), 54-57.

19. Yevlakhova, L.A., Chava, S.V., Akyyeva, N.K. (2013), «Strukturnyye osobennosti beloy pulpy selezyonki u myshey posle radiatsionnogo vozdeystviya nizkoy intensivnosti». Morfologicheskiye vedomosti, 2, 98100. eLIBRARY ID: 21477954.

20. Zanfirescu, A., Cristea, A.N., Nitulescu, G.M., Velescu, B.S., «Gradinaru, D. (2018), Chronic Monosodium Glutamate Administration Induced Hyperalgesia in Mice». Nutrients, $10,1$. https://doi.org/10.3390/nu10010001. 